\title{
Importance of Multidisciplinary and Regional Collaboration in Integrated West Nile Virus Surveillance - the „One Health" Concept
}

\section{Značaj multidisciplinarne i regionalne suradnje u integriranom nadzoru West Nile virusa} - koncept "Jedno zdravlje"

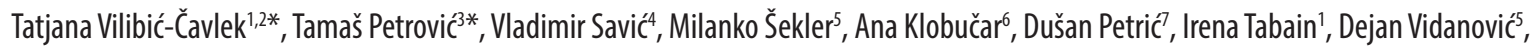

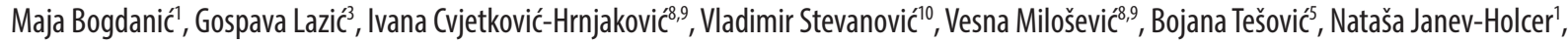

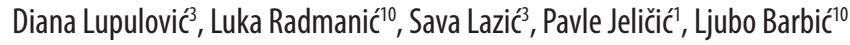

*authors with equal contribution

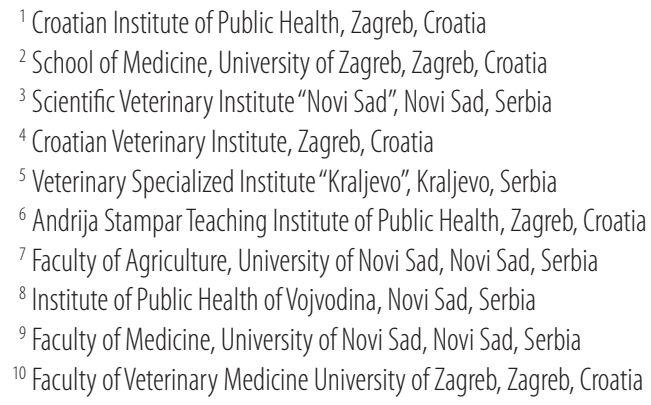

Keywords:

West Nile virus

surveillance

"One Health"

Croatia

Serbia

Ključne riječi:

West Nile virus

nadzor

"edno zdravlie"

Hrvatska

Srbija

Primljeno: 10.1.2019.

Received: 10.1.2019.

Prihvaćeno: 18.2.2019

Accepted: 18.2.2019.

$\triangle$ Corresponding author

Author for correspondence:

Tatjana Vilibić-Čavlek, MD, PhD

Croatian Institute of Public Health

Rockefellerova 12, 10000 Zagreb, Croatia

E-mail: tatjana.vilibic-cavlek@hzjz.hr

\section{Abstract}

West Nile virus (WNV) is nowadays one of the most widely distributed arboviruses. In the last two decades, small or large WNV epidemics and epizootics are continuously reported in Europe. In this review, we present the epidemiological characteristics of WNV infections detected in Croatia and Serbia within the "One Health" context. Presented results confirm the importance of multidisciplinary and regional collaboration in the diagnosis and surveillance of this (re-)emerging viral zoonosis.

\section{Introduction}

The epidemiology of West Nile virus (WNV) is continuously changing and currently, WNV is one of the most widely distributed arboviruses. In nature, virus is maintained in an enzootic cycle involving birds

\begin{abstract}
Sažetak
West Nile virus (WNV) danas je jedan od najrasprostranjenijih arbovirusa. U posljednja se dva desetljeća WNV infekcije kontinuirano pojavljuju na području Europe u obliku manjih ili većih epidemija i epizootija. U ovom preglednom radu prikazujemo epidemiološke značajke WNV infekcija koje su dokazane na području Hrvatske i Srbije u kontekstu "Jednog zdravlja". Prikazani rezultati potvrđuju značaj multidisciplinarne i regionalne suradnje u dijagnostici i praćenju ove (re-)emergentne virusne zoonoze.
\end{abstract}

and mosquitoes, while humans and horses represent incidental or "dead-end" hosts. Mosquitoes of the genus Culex are the major vectors of WNV globally, but virus is also detected in some other mosquito species (Aedes, Ochlerotatus) ${ }^{[1]}$. There are several genetic 
lineages of which WNV lineage 1 and 2 are the most widespread. After the first isolation of WNV in Uganda (1937), sporadic WNV cases were recorded in the subsequent years. Since the 1950s, serological surveys have shown that the virus has been circulating outside its original ecological niches, including Europe ${ }^{[2]}$. Epidemiology of WNV has changed since the mid-1990s. Outbreaks associated with severe neuroinvasive disease began to occur in North Africa (Algeria, Tunisia, Sudan), Europe (Italy, Romania, Russia), Israel and $\mathrm{USA}^{[3]}$, mainly caused by WNV lineage 1 strains ${ }^{[4]}$. Since 2002, outbreaks among humans and horses were continuously reported in many European countries, with annual epidemic cycles in some countries related to the spread of WNV lineage 2 strains ${ }^{[5]}$. In the 2018 transmission season, the highest number of cases was reported in Europe compared with previous years with a total of 2,083 autochthonous human WNV infections. In addition, $285 \mathrm{WNV}$ outbreaks among equids were reported, which represents $30 \%$ increase compared to the number of outbreaks in $2017^{[6]}$. Like in other European countries, WNV infections were continuously reported in Croatia and Serbia. In this review, the epidemiology of WNV infections in these two neighbouring countries was analysed within the integrated multidisciplinary "One Health" concept.

\section{West Nile Virus Infections in Croatia}

\section{WNV Human Infections}

In Croatia, serologic evidence of human WNV infections dates back to 1970s. In two studies conducted among residents of the Island Brač in 1970 and 1974, the seroprevalence of hemagglutination inhibiting (HI) antibodies was $4.9 \%$ and $0.28 \%$, respectively ${ }^{[7]}$. A further survey conducted in 1980 found positive HI results in $1.2 \%$ inhabitants from North-Eastern Croatia, 3.4\% from Middle and 0.8\% from Southern Dalmatia ${ }^{[8]}$. In 2007, WNV neutralizing (NT) antibodies were detected in $0.3 \%$ voluntary blood donors in North-Eastern Croatia ${ }^{[9]}$. Similar seroprevalence rate of $0.3 \%$ was noted in a group of randomly selected asymptomatic persons aged 30-60 years tested during $2011^{[10,11]}$. First clinical cases of neuroinvasive WNV infections in Croatia were reported in 2012 in two eastern counties ${ }^{[12,13]}$. In 2013 outbreak, 19 cases were detected in Zagreb and its surroundings and one case in Međimurje (north-western region) ${ }^{[14]}$. In the subsequent years, only sporadic cases were notified until 2017 when a small outbreak with 8 reported cases occurred in five continental counties ${ }^{[15,16]}$. The largest outbreak of WNV infections so far occurred in 2018 with 54 neuro-invasive infections and 7 WNV fever detected in 10 continental Croatian counties. All cases were confirmed by detection of WNV RNA or WNV NT antibodies ${ }^{[17]}$. In addition to acute WNV infections, seropositive persons were continuously detected in counties with reported clinical cases ${ }^{[18]}$. Data on the genetic characterization showed that all detected Croatian virus strains belonged to WNV lineage $2^{[16,17,19]}$. So far, there are no WNV infections reported among the inhabitants of the Croatian littoral.

\section{WNV Infections in Horses}

First WNV seropositive horses in Croatia were detected during 2001-2002 $2^{[20]}$. In 2010-2011, a detection of WNV antibodies was performed in horse and cattle serum samples. WNV NT antibodies were present in $3.43 \%$ of horses and $0.11 \%$ cattle with the highest seroprevalence in Eastern Croatian regions bordering Hungary and Serbia. At the Adriatic coast, seropositive animals were found only in the westernmost Istria County, near Slovenian and Italian borders. The results of the study showed that WNV infections are widely spread among horses in different Croatian regions $^{[21]}$. During the 2012 Croatian outbreak, acute asymptomatic WNV infections in horses (IgM positive) were detected for the first time in the same counties where human cases occurred. Acute infections were confirmed 2-4 weeks before first human clinical case reported. A seroprevalence study conducted in six counties showed an average WNV IgG seroprevalence of $8.7 \%$. The seropositivity varied greatly from $2.2 \%$ to $17.4 \%$ with the highest seroprevalence in counties where human cases were documented ${ }^{[22]}$. Acute asymptomatic infections in sentinel horses were notified continuously in the following transmission seasons. IgM positive animals were detected in 9 continental counties and two counties at the Croatian littoral ${ }^{[23,24]}$. In addition, since 2012, sentinel horses from all Croatian counties were tested annually to WNV as a part of the national flavivirus surveillance program. IgG seroprevalence rates were found to be: $0-22.7 \%$ in $2013,0-29.6 \%$ in $2014,0-34.2 \%$ in $2015,0-24.3 \%$ in $2016^{[25,26]}, 0-24.0 \%$ in 2017 and $0-26.0 \%$ in $2018^{[17]}$. In 2013, WNV IgG seropositive horses were detected in 11 continental counties and two counties at the Croatian littoral. In addition, during 2014-2016, WNV IgG seropositivity in horses was documented in all continental counties and all seven counties at the littoral as well. However, the highest virus activity was continuously notified in eastern continental counties (data of the Faculty of Veterinary Medicine University of Zagreb).

\section{West Nile Infections in Poultry}

The first serological evidence of WNV infection in poultry in Croatia was reported in 2013 in Međimurje County. Within a flavivirus surveillance program, dur- 
ing a three-year period (2013-2015), serum samples from sentinel outdoor chickens were tested for WNV IgG antibodies with a seroprevalence rate of $11.5 \%$ ranging from $3.1 \%$ to $22.9 \%{ }^{[24]}$. Serological surveys conducted during 2016-2018 transmission seasons showed WNV IgG seropositivity of $1.8 \%, 10.4 \%{ }^{[16,27,28]}$ and $12.7 \%$ (data of the Poultry Center, Croatian Veterinary Institute), respectively. Poultry included in surveys were older than three weeks and hatched in the current year to assure a reliable demonstration of the viral activity in the current transmission season and exclusion of maternally derived antibodies as well as WNV antibodies from previous seasons. Seropositive poultry were detected in all continental counties.

\section{West Nile Infections in Wild Birds}

In September 2018, WNV was detected for the first time in wild birds in Croatia. Brain tissue of 35 dead wild birds from families Passeridae (25), Accipitridae (4), Laridae (3), Anatidae (1), Ciconiidae (1) and Turdidae (1) were analysed for the presence of WNV RNA. A female and a male goshawk (Accipiter gentilis) from the same aviary in Međimurje County were RTPCR positive. Also, WNV RNA was detected in one blackbird (Turdus merula) from Split-Dalmatia County. Phylogenetic analysis showed WNV lineage 2. In addition, WNV infection was serologically confirmed in one buzzard (Buteo buteo) with neurological symptoms from Međimurje County ${ }^{[17]}$.

\section{West Nile Infections in Mosquitoes}

After the first report of human WNV infections, entomological surveys were continuously performed. During the 2012 outbreak in Croatia, mosquitoes were sampled within the area of appearance of WNV neuro-invasive human cases in three north-eastern counties. All tested $C x$. pipiens complex pools were negative for WNV RNA using pan-flavivirus RT-PCR ${ }^{[29]}$. In the period from 2015 to 2018, mosquitoes were collected in Zagreb and its surroundings. So far, no one of the tested Cx. pipiens and Ae. albopictus mosquito pool was positive for $\mathrm{WNV}^{[30,31]}$.

\section{West Nile Virus Infections in Serbia}

\section{WNV Infections in Humans}

The history of WNV infection among human population in Serbia is mostly unknown. Due to the lack of routine diagnostic practices in the past, human cases of meningoencephalitis of "unknown" origin that should have been submitted to laboratory testing for the WNV presence were neglected in Serbia up until 2012. First serological studies showed low prevalence of WNV antibody positive serum samples, indicating possibly very low or sporadic circulation of $\mathrm{WNV}$ in the past in the territory of Serbia. In 1972, Bordjoški et al. found anti-WNV antibodies in $2.6-4.7 \%$ of tested human serum samples ${ }^{[32]}$. In another study, antibodies to $\mathrm{WNV}$ were detected, depending on the location, in $1-8 \%$ of tested samples ${ }^{[33]}$. After a gap of many years, more recent serological examinations revealed the presence of WNV IgG antibodies in 3.99\% human samples collected from 2005 to 2010 in Vojvodina with yearly rates varying between $1.97 \%$ and $6.04 \%{ }^{[34]}$. In 2012 , for the first time an outbreak of WNV infection in humans was reported in Serbia ${ }^{[35,36]}$, being the first time that WNV infections has been associated with clinical symptoms. A total of $71 \mathrm{WNV}$ cases were reported, among which 42 were confirmed. All cases were detected in central and northern part of the country ${ }^{[37-39]}$. This epidemic continued and became even more severe during 2013. A total of $303 \mathrm{WNV}$ cases were reported, among which 202 were confirmed. Almost all cases were again detected in central and northern part of the country (data of the Institute of Public Health of Serbia). The human WNV epidemic also continued during 2014 with the similar characteristics to those in 2012. In total, 76 clinical cases of WNV infection were reported. Almost all cases were detected in central and northern part of the country, and 65 out of 76 (86\%) of them were detected in four districts (Belgrade, South Banat, South Bačka and Srem $)^{[40]}$. During 2015, 28 confirmed human cases were reported. Almost all cases (27/28) were detected in central and northern part of the country, and 25 out of $28(86 \%)$ were from the same four districts as the season before $^{[41]}$. During 2017, a total of 49 WNV human cases were detected (data of the Institute of Public Health of Serbia). WNV infections were detected from the beginning of August until October 2017 in six out of 25 districts in Serbia ${ }^{[42,43]}$. According to the ECDC weekly updates for 2018 West Nile fever transmission, from EU neighbouring countries in total 580 human cases were reported, out of that number 415 in Serbia. Human cases were reported in 13 out of 25 districts in Serbia ${ }^{[6]}$.

\section{WNV Infections in Horses}

In Serbia, WNV situation was mostly unknown until 2009. During 2009-2010, a serological testing of horse samples showed that $12 \%$ horses from the northern part of the country had specific WNV NT antibodies. Positive horses were found in 14/28 municipalities studied ${ }^{[44]}$. During 2007-2011 study, the presence of WNV specific antibodies was found in $28.6 \%$ horse serum samples collected from 7 big stables located in Vojvodina Province (northern part of Serbia) and Belgrade area. WNV seroprevalence ranged from $13.3 \%$ up to $40 \%$ seropositive animals per stable ${ }^{[45]}$. Just one year later, immediately 
after the human WNV outbreak in 2012, WNV IgG antibodies were detected in $49.23 \%$ of horse serum samples from six stables and one settlement in Vojvodina Province. The percentage of seropositive animals varied from $35 \%$ to $64 \%$ per stable. The $49.23 \%$ seroprevalence in horses during 2012 was much higher than in previous studies conducted in horses in Serbia, confirming an intensive WNV circulation during $2012^{[46]}$. Similarly, in 2013 , the $46.88 \%$ horse seroprevalence from five stables indicated the continuation of the intensive WNV circulation. During the national surveillance program in the period June-September 2014, serum samples of sentinel horses previously seronegative for WNV, were collected from all 25 districts of Serbia. Seroconversion was detected in 6.91\% of tested sentinel horses during all three tested months (June-August). With the increase of the vector's activity, positive serological response was determined in $0.53 \%, 1.38 \%$ and $6.32 \%$ of horses during the tested period. Seroconversion was detected in 11/25 districts under the surveillance ${ }^{[47]}$. During 2015, population of horses from the whole country was tested for WNV IgM antibodies. Positive serological response was detected in $0.53 \%$ horses. WNV IgM positive horses were detected during all four tested months (June-September) with the highest prevalence in the period of the most intense vectors' activity. The percentage of seropositive animals in June was $0.13 \%$, July $0.12 \%$, August $1.11 \%$ and in September $0.77 \%$. IgM positive horses were detected in 8/25 districts in Serbia. In June 2015, the first seropositive horse was detected from Belgrade area ${ }^{[47]}$. During 2016, horses were not tested for WNV infection since the WNV national surveillance program was not in force, but during 2017, the similar situation as in 2015 was observed. In contrast, during the 2018 WNV national surveillance program much more intensive WNV circulation was observed. WNV IgM antibodies were detected in almost $2 \%$ of tested horses from 13/25 districts of Serbia (unpublished data). In July 2018, the first clinical case of neurological WNV infection presented with hypersensitive skin reaction, disorientation, weakness, ataxia and the loss of equilibrium was reported in a Belgian sports mare in Belgrade ${ }^{[48]}$.

\section{WNV Infections in Poultry}

The first data on WNV infection in domestic poultry was obtained during 2013. Young poultry (hatched during that year to exclude the seropositive animals infected with WNV during previous seasons) from five large commercial poultry farms and 10 backyards from five settlements were tested for the presence of WNV IgG antibodies in November at the end of vector activity season. None of the farm poultry were seropositive but $40-60 \%$ of the young backyard poultry were positive for WNV IgG antibodies, indicating that they were infected during 2013 (unpublished study). The discrepancy between the poultry from commercial farms and backyards might be explained by differences in biosecurity level including the insect control as well as by the ratio of number of mosquitoes per animal at large commercial poultry farms and in the backyards. During the national surveillance program conducted in 2014, the backyard poultry were used as sentinel animals. The results of this surveillance showed that the positive serological response was detected in 5.75\% young poultry sampled from the whole country. Seroconversion was detected in all four months of the surveillance with the highest positive serological response during August and September (in 8.91\% and 8.21\% animals, respectively). Positive serological response was recorded in backyard sentinel poultry in $17 / 25$ $(68 \%)$ districts of Serbia ${ }^{[47]}$.

\section{WNV Infections in Wild Birds}

The first study on WNV presence in wild birds confirmed intensive WNV circulation in Serbia during 2012. WNV antibodies were detected by ELISA and PRNT in 7.6\% serum samples and the virus presence was confirmed by real-time RT-PCR in $9.87 \%(8 / 81)$ of tested tissue samples and in one blood sample out of 133 dead and live captured wild resident and migratory birds ( 45 species within 27 families) sampled from January until September 2012 in Vojvodina Province. Most of the WNV antibody or virus positive birds were strictly resident, suggesting endemic presence of WNV in Serbia. All WNV isolates were typed as a lineage 2 strains that were highly similar to the viruses responsible for the human and animal outbreaks reported in neighbouring countries ${ }^{[49]}$. The presence of WNV in wild birds was also confirmed during the national WNV surveillance programs funded by the Veterinary Directorate from 2014 until 2018 (with exception of 2016 when surveillance was not done). During 2014 wild bird surveillance, WNV was detected in only two birds (in tissue samples of a dead cormorant in July and a magpie shot dead in September). Both WNV positive wild birds were detected in Vojvodina Province. Out of 736 live wild birds pharyngeal swab samples tested for WNV none was positive. During the program conducted in 2015 , WNV was detected in $2 / 183(1.09 \%)$ tissue samples of found dead wild birds and in 3/13 tissue samples of shot dead Eurasian magpies. Similar to the results obtained during 2014, all detected WNV positive wild birds were from Vojvodina Province and the territory of Belgrade ${ }^{[47]}$. During 2017, much the same results as previous years were obtained, but during 2018 WNV was detected in more than $10 \%$ of found dead wild birds (unpublished data). 


\section{WNV Infections in Mosquitoes}

The first studies on the presence of WNV in mosquitoes in Serbia date back to the period 2005-2010. A total of 56,757 mosquitoes originating from 66 localities in 29 settlements in Vojvodina Province were examined. The presence of WNV genome was detected only in 3/841 tested pools. In 2010, WNV positive pools were found in the city of Novi Sad, and the sequenced isolate was typed as WNV lineage $2^{[33]}$. These studies were continued during 2012 and 2013, when a significant increase in the prevalence of WNV in mosquitoes was established. Even more than $9 \%$ of the mosquito pools examined during 2012-2013, mainly of the species Culex pipiens (both biotypes molestus and pipiens), tested positive for WNV RNA (unpublished data). During the national surveillance program conducted in 2014, the earliest WNV positive mosquito pools were detected in the middle of July. In total, WNV was detected in $2.31 \%$ of tested mosquito pool samples collected throughout the country. The highest WNV prevalence in mosquitoes was detected during September (9.68\%). WNV positive mosquitoes were detected in 8/25 (32\%) districts of Serbia. All districts where WNV positive mosquito pools were detected, except Raška District, are in Vojvodina Province ${ }^{[47]}$. Such result can be attributed to the fact that this region has previously been confirmed as the region with intensive WNV circulation in the past years ${ }^{[34,44,46,49]}$. During the national surveillance program conducted in 2015, WNV was detected in 2.09\% of tested mosquito pooled samples. The highest prevalence of WNV in mosquitoes was found during August (4.92\% positive samples). WNV positive mosquitoes were detected in only 6/25 (24\%) districts of Serbia, and all are in Vojvodina Province ${ }^{[47]}$. From 2010 to 2015 , WNV was detected in mosquitoes sampled at 43 different trap stations across Vojvodina Province. At 14 stations (32.56\%), WNV was detected in two different (consecutive or alternate) years, at two stations in three different years, and in one station during five different years ${ }^{[50]}$. WNV presence in mosquitoes detected during the surveillance program during 2017 was quite similar to the results from years 2014 and 2015. Opposite to this, WNV was detected in more than $20 \%$ of mosquito pools tested from June to August 2018 indicating more intense virus circulation (unpublished data).

\section{Conclusions}

Many published studies confirmed active circulation and endemic presence of WNV in both Croatia and Serbia. Emergence and molecular epidemiology of WNV infections in humans, horses, poultry, wild birds and mosquitoes ("One health" concept) are pre- sented in tables 1 and 2. Based on the obtained results and anticipated intense circulation of WNV that poses substantial risks for both public and animal health, flavivirus surveillance programs in sentinel animals were established. The principal objective of the programs was early detection of WNV, timely reporting to human health service institutions and local authorities in order to inform the local communities and for establishing the control of mosquitoes and preventive measures for human health protection. The WNV surveillance programs were based on direct and indirect surveillance of WNV presence in natural environment, by serological testing of seronegative sentinel horses and poultry as well as through virus detection in pooled mosquito samples and samples from wild birds ${ }^{[47,49-51]}$. Considering the results obtained during the WNV surveillance programs in 2014 and 2015 and reported human cases in those years, it could be concluded that the conducted WNV surveillance programs were successful and meaningful. Most of the human cases were preceded by the detection of WNV in animals and/or mosquitoes ${ }^{[47,52]}$. The same or similar situation was observed during the WNV surveillance programs in 2017 and 2018, when the most intensive WNV circulating was observed so far.

In conclusions, it is important to highlight the similarity between epidemiological and epizootiological characteristics of WNV emergence in Croatia and Serbia. Human clinical cases of WNV infection were confirmed in the same transmission season 2012. From the first appearance, majority of clinical cases were recorded in eastern part of Croatia and central and northern part of Serbia. Detection of human clinical cases in the consecutive transmission seasons in these areas indicate that eastern Croatia and central/northern parts of Serbia represent the same large endemic area for WNV. In both countries, confirmation of viral activity in wild birds and mosquitoes and/or infections in sentinel animals preceded human clinical cases. Since its emergence in 2012, WNV has become an endemic disease in our countries and epidemiological and epizootiological data implicate that transmission season starts few weeks earlier in Serbia. All presented results confirm that harmonized WNV surveillance program on the interstate level within the "One health" concept and intensive multidisciplinary collaboration is the most efficient mode to control this important (re-)emerging viral zoonosis.

\section{Acknowledgment}

This study was supported in part by the Croatian Science Foundation, project No. HRZZ IP 2016-06-7456: Prevalence and molecular epidemiology of emerging 
and re-emerging neuro-invasive arboviral infections in Croatia; CRONEUROARBO (to TVC); by the project No. TR31084 funded by the Serbian Ministry of Education, Science and Technological Development; and by bilateral project funded by Croatian Ministry of Science and Education and Serbian Ministry of Education, Science and Technological Development:
"Optimization of diagnosis and surveillance of emerging and re-emerging viral vector-borne zoonosis" (to $\mathrm{LjB}$ and $\mathrm{TP}$ ). National WNV monitoring program in Serbia was funded by Veterinary Directorate of Serbian Ministry of Agriculture, Forestry and Water management and the Croatian and Serbian Ministry of Science and Education.

Table 1. Surveillance of West Nile infections in the "One Health" concept, 2010-2018

\begin{tabular}{|c|c|c|c|c|c|c|c|c|c|}
\hline & 2010 & 2011 & 2012 & 2013 & 2014 & 2015 & 2016 & 2017 & 2018 \\
\hline \multicolumn{10}{|l|}{ CROATIA } \\
\hline Human infections & & & $x$ & $x^{*}$ & $x$ & $x$ & $x$ & $X^{*}$ & $x^{*}$ \\
\hline Infections in horses & & & $x$ & $x$ & $x$ & $x$ & $x$ & $x$ & $x$ \\
\hline Infections in poultry & & & $x$ & $x$ & $x$ & $x$ & $\times$ & $x$ & $x$ \\
\hline Infections in wild birds & & & & & & & & & $x^{*}$ \\
\hline \multicolumn{10}{|l|}{ Positive mosquito pools } \\
\hline \multicolumn{10}{|l|}{ SERBIA } \\
\hline Human infections & & & $x$ & $x^{*}$ & $x$ & $\times$ & $\times$ & $x$ & $x^{*}$ \\
\hline Infections in horses & $x$ & $x$ & $x$ & $\times$ & $x$ & $x$ & NT & $x$ & $x$ \\
\hline Infections in poultry & & & & $x$ & $x$ & & & & \\
\hline Infections in wild birds & & & $x^{*}$ & $x^{*}$ & $x^{*}$ & $x^{*}$ & NT & $x^{*}$ & $x^{*}$ \\
\hline Positive mosquito pools & $x^{*}$ & & $x^{*}$ & $x^{*}$ & $x^{*}$ & $x^{*}$ & $x^{*}$ & $x^{*}$ & $x^{*}$ \\
\hline
\end{tabular}

$\times$ Acute WNV infections $\quad$ WNV IgG seropositivity $*$ Sequenced WNV strains $\quad$ NT $=$ Not tested

Table 2. Molecular epidemiology of West Nile Virus infections, 2010-2018

\begin{tabular}{|c|c|c|c|c|c|c|c|c|c|}
\hline & 2010 & 2011 & 2012 & 2013 & 2014 & 2015 & 2016 & 2017 & 2018 \\
\hline \multicolumn{10}{|l|}{ CROATIA } \\
\hline Human infections & & & & Lineage 2 & & & & Lineage 2 & Lineage 2 \\
\hline \multicolumn{10}{|l|}{ Infections in horses } \\
\hline \multicolumn{10}{|l|}{ Infections in poultry } \\
\hline Infections in wild birds & & & & & & & & & Lineage 2 \\
\hline \multicolumn{10}{|l|}{ Positive mosquito pools } \\
\hline \multicolumn{10}{|l|}{ SERBIA } \\
\hline Human infections & & & & Lineage 2 & & & Lineage 2 & Lineage 2 & Lineage 2 \\
\hline Infections in horses & & & & & & & NT & & \\
\hline \multicolumn{10}{|l|}{ Infections in poultry } \\
\hline Infections in wild birds & & & & Lineage 2 & Lineage 2 & Lineage 2 & NT & Lineage 2 & Lineage 2 \\
\hline Positive mosquito pools & Lineage 2 & & Lineage 2 & Lineage 2 & Lineage 2 & Lineage 2 & Lineage 2 & Lineage 2 & Lineage 2 \\
\hline
\end{tabular}

Acute WNV infections/WNV RNA detection 


\section{REFERENCES}

${ }^{[1]}$ Vogels CB, Göertz GP, Pijlman GP, Koenraadt CJ. Vector competence of European mosquitoes for West Nile virus. Emerg Microbes Infect 2017; 6(11):e96.

${ }^{[2]}$ Rizzoli A, Jiménez-Clavero MA, Barzon L, et al. The challenge of West Nile virus in Europe: knowledge gaps and research priorities. Euro Surveill 2015; 20(20):pii=21135.

${ }^{[3]}$ Calistri P, Giovannini A, Hubalek Z, et al. Epidemiology of West Nile in Europe and in the Mediterranean Basin. Open Virol J 2010; 4:29-37.

${ }^{[4]}$ Zeller HG, Schuffenecker I. West Nile virus: an overview of its spread in Europe and the Mediterranean Basin in contrast to its spread in the Americas. Eur J Clin Microbiol Infect Dis $2004 ; 23: 147-56$.

${ }^{[5]}$ Bakonyi T, Ferenczi E, Erdélyi K, et al. Explosive spread of a neuroinvasive lineage 2 West Nile virus in Central Europe, 2008/2009. Vet Microbiol 2013; 165(1-2):61-70.

${ }^{[6]}$ European Centre for Disease Prevention and Control (ECDC). Epidemiological update: West Nile virus transmission season in Europe, 2018. Available at: http:// ecdc.europa.eu/en/newsevents/epidemiological-update-west-nile-virus-transmission-season-europe-2018

${ }^{[7]}$ Vesenjak-Hirjan J, Galinovic-Weisglass M, Brudnjak Z, et al. Island of Brač - Focus of Arbovirus Infections. In: Vesenjak-Hirjan J (ed). Arboviruses in the Mediterranean Countries. ZbL. Bakt. Suppl 9, Gustav Fischer Verlag: Stuttgart-New York, 1980; pp 311-7.

${ }^{[8]}$ Vesenjak-Hirjan J. Arboviruses in Yugoslavia. In: Vesenjak-Hirjan J (ed). Arboviruses in the Mediterranean Countries. ZbL. Bakt. Suppl 9, Gustav Fischer Verlag: Stuttgart-New York, 1980; pp 165-77.

${ }^{[9]}$ Golubić D, Dobler G. Flaviviruses in North-West Croatia. Croat J Infect 2012; 32(4):153-7. (In Croatian)

${ }^{[10]}$ Vilibić-Čavlek T, Pem-Novosel I, Gjenero-Margan I, et al. Human West Nile virus infection in eastern Croatia, August-September, 2012. Rad HAZU, Med Sci, 2013; 39:73-80.

${ }^{[11]}$ Vilibić-Čavlek T, Barbić Lj, Ljubin-Sternak S, et al. West Nile infection: a re-emerging disease in Croatia. Liječ Vjesn 2013; 135:156-61. (In Croatian)

${ }^{[12]}$ Pem-Novosel I, Vilibic-Cavlek T, Gjenero-Margan I, et al. First outbreak of West Nile virus neuroinvasive disease in humans, Croatia, 2012. Vector-Borne Zoonotic Dis 2014; 14(1):82-4.

${ }^{[13]}$ Perić Lj, Šimašek D, Vilibić-Čavlek T, et al. Clinical aspects of West Nile virus infections in humans in Croatia. Rad HAZU, Med Sci, 2013; 39:81-8.

${ }^{[14]}$ Vilibic-Cavlek T, Kaic B, Barbic Lj, et al. First evidence of simultaneous occurrence of West Nile virus and Usutu virus neuroinvasive disease in humans in Croatia during the 2013 outbreak. Infection 2014; 42:689-95.

${ }^{[15]}$ Pandak N, Vilibić-Čavlek T, Barbić Lj, et al. How much and what do we know about West Nile infection? Croat J Infect 2015; 35(2-3):53-60. (In Croatian)

${ }^{[16]}$ Vilibić-Čavlek T, Avšič-Županc T, Babić-Erceg A, et al. Prevalence and molecular epidemiology of emerging and re-emerging arboviral infections in Croatia, 2017. In: Petrović T (ed.) Book of Abstracts. XX Symposium of Epizootiologists and Epidemiologists. Vrnjačka Banja, Serbia, 18-20 April, 2018, p37
${ }^{[17]}$ Vilibic-Cavlek T, Savic V, Sabadi D, et al. Prevalence and molecular epidemiology of West Nile and Usutu virus infections in Croatia in the 'One health' context, 2018. Transbound Emerg Dis. 2019;66(5):1946-1957.

${ }^{[18]}$ Vilibic-Cavlek T, Stevanovic V, Pem-Novosel I, et al. A serologic survey of West Nile virus and Usutu virus in Croatia. Book of Abstracts. 24nd ECCMID, Barcelona, Spain, 10-13 May, 2014. P0434

${ }^{[19]}$ Kurolt IC, Krajinović V, Topić A, Kuzman I, Baršić B, Markotić A. First molecular analysis of West Nile virus during the 2013 outbreak in Croatia. Virus Res 2014; 189:63-6.

${ }^{[20]}$ Madić J, Savini G, Di Gennaro A, et al. Serological evidence for West Nile Virus infection in horses in Croatia. Vet Rec 2007; 160:772-3

${ }^{[21]}$ Barbić Lj, Listeš E, Katić S, et al. Spreading of West Nile virus infection in Croatia. Vet Microbiol 2012; 159:504-8.

${ }^{[22]}$ Barbić Lj, Stevanović V, Kovač S, et al. West Nile virus serosurveillance in horses in Croatia during the 2012 transmission season. Rad HAZU, Med Sci, 2013; 39:95-104.

${ }^{[23]}$ Barbic Lj, Stevanovic V, Vilibic-Cavlek T, et al. Serosurveillance of WNV in horses-useful tool for public health. Book of Abstracts. 24nd ECCMID, Barcelona, Spain, 10-13 May, 2014. P0449

${ }^{[24]}$ Savić V, Barbić Lj, Vilibić-Čavlek T, et al. Chickens and horses as sentinels for early warning system in prevention of human West Nile virus infections in Croatia. 6th Slovenian Veterinary Congress, Portorož, December 2-3, 2016. Slov Vet Res 2016; 53(Suppl 17):292-4.

${ }^{[25]}$ Barbić Lj, Vilibić-Čavlek T, Stevanović V, et al. "One health" - detection and surveillance of emerging and re-emerging arboviruses in Croatia. Croat J Infect 2015; 35(2-3):61-6. (In Croatian)

${ }^{[26]}$ Barbić Lj, Stevanović V, Hađina S, Vilibić-Čavlek T, Madić J. Emerging viruses of zoonotic and the veterinary importance in Croatia. Book of Abstracts. Conference-Emerging Viruses of Zoonotic and Veterinary Importance, Cambridge, United Kingdom 24-26 July, 2017.

${ }^{[27]}$ Savić V, Barbić L, Vilibić-Čavlek T, et al. West Nile virus in birds and poultry and its implication on public health. Book of Abstracts. 5th International Veterinary Poultry Congress. Tehran, Iran, 31 January-1 February, 2016.

${ }^{[28]}$ Savić V. West Nile virus and Usutu virus in wild birds in Croatia. In: Vilibić Čavlek T, Barbić Lj, Savić V (eds.): Book of Abstracts. Workshop with International Participation: Emerging and Neglected Zoonoses in the "One Health" Context. Zagreb: Croatian Institute of Public Health, 2018, pp35-36. (In Croatian)

${ }^{[29]}$ Merdic E, Vignjevic G, Turic N, et al. Mosquito survey during West Nile virus outbreak 2012 in northeast Croatia. Coll Antropol 2014; 38:423-428.

${ }^{[30]}$ Klobucar A, Benic N, Krajcar D, et al. An overview of mosquitoes and emerging arboviral infections in the Zagreb area, Croatia. J Infect Dev Ctries 2016; 10(12):1286-93.

${ }^{[31]}$ Klobučar A, Petrinić S, Savić V, et al. First detection of arboviruses in mosquitoes in Croatia. In: Kružić P, Caput Mihalić K, Gottstein S, Pavoković D, Kučinić M. (ed.) Book of Abstracts. 13th Croatian Biology Congress with International participation. Poreč, 19-23 September 2018, p21 
${ }^{[32]}$ Bordjoški M, Gligic A, Boskovic R. Arboviral infections in Serbia. Vojnosanit Pregl 1972; 29(4):173-175. (In Serbian)

${ }^{[33]}$ Vesenjak-Hirjan J, Punda-Polić V, Dobec M. Geographical distribution of arboviruses in Yugoslavia. J Hyg Epidemiol Microbiol Immunol (Prague) 1991; 35:129-40.

${ }^{[34]}$ Petrić D, Hrnjaković Cvjetković I, Radovanov J, et al. West Nile virus surveillance in humans and mosquitoes and detection of cell fusing agent virus in Vojvodina province (Serbia). HealthMED 2012; 6(2):462-8.

${ }^{[35]}$ EpiSouth Weekly Epi Bulletin-No232, 22nd August-28th August 2012 (e-WEB). Available at: http://www.episouthnetwork. $\mathrm{org} /$ sites/default/files/bulletin_file/eweb_232_30_08_12.pdf

${ }^{[36]}$ EpiSouth Weekly Epi Bulletin-N²40, 17 October-23 October 2012 (e-WEB). Available at: http://www.episouthnetwork.org/ sites/default/files/bulletin_file/eweb_240_25_10_12.pdf

${ }^{[37]}$ ECDC. Reported cases of West Nile fever for the EU and neighbouring countries. Situations update 30 November 2012. Available at: http://ecdc.europa.eu/en/healthtopics/west_nile_ fever/West-Nile-fevermaps/Pages/historical-data.aspx

${ }^{[38]}$ Obrenović J, Grgić B, Lončarević G, et al. Report on infectious diseases in 2012 in the Republic of Serbia. Institut of Public Health Republic of Serbia "Dr Milan Jovanović Batut", 2013. (In Serbian)

${ }^{[39]}$ Popović N, Milošević B, Urošević A, et al. Outbreak of West Nile virus infection among humans in Serbia, August to October 2012. Euro Surveill. 2013; 18(43):pii=20613.

${ }^{[40]}$ ECDC. Reported cases of West Nile fever for the EU and neighbouring countries. Situations update 20. November 2014. Available from: http: //ecdc.europa.eu/en/healthtopics/ west_nile_fever/West-Nile-fever-maps/Pages/2014-table.aspx

${ }^{[41]}$ ECDC. Cumulative number of West Nile fever cases by affected area in 2015. Available from:http://ecdc.europa.eu/ en/healthtopics/west_nile_fever/West-Nile-fever-maps/Pages/2015-table.aspx

${ }^{[42]}$ Report of the actual epidemiological situation on West Nile fever in Serbia, 2017. Available at: http://www.batut.org.rs/download/aktuelno/Informacija\%20o\%20GZN\%20 27.10.2017.pdf (in Serbian)
${ }^{[43]}$ ECDC. Transmission of West Nile fever, May to November 2017 - Table of cases, 2017. Available at: https://ecdc.europa. $\mathrm{eu} / \mathrm{en} /$ publications-data/table-transmission-west-nile-fevermay-november-2017-table-cases-2017).

${ }^{[44]}$ Lupulović D, Martín-Acebes M, Lazić S, et al.First Serological Evidence of West Nile Virus Activity in Horses in Serbia. Vector-Borne Zoonotic Dis 2011; 11(9):1303-05.

${ }^{[45]}$ Medić S, van den Hoven R, Petrović T, Lupulović D, Nowotny N. Serological evidence of West Nile virus infection in the horse population of northern Serbia. J Infect Dev Ctries 2014; 8(7):914-918.

${ }^{[46]}$ Petrović T, Lazić S, Lupulović D, et al. Serological study on WNV presence in horses in Vojvodina after the human outbreak in Serbia in 2012. Arch Biol Sci Belgrade 2014; 66(2): 473-81.

${ }^{[47]}$ Petrović T, Šekler M, Petrić D, et al. Methodology and results of integrated WNV surveillance programmes in Serbia. PLoS One 2018; 13(4): e0195439.

${ }^{[48]}$ Medić S, Lazić S, Petrović T, et al. Evidence of the first clinical case of equine neuroinvasive West Nile disease in Serbia, 2018. Acta Vet-Beograd 2019; 69(1):123-30.

${ }^{[49]}$ Petrović T, Blazquez A, Lupulović D, et al. Monitoring West Nile virus (WNV) infection in wild birds in Serbia during 2012: first isolation and characterisation of WNV strains from Serbia. Euro Surveill 2013; Vol 18(44):1-8.

${ }^{[50]}$ Petrić D, Petrović T, Hrnjaković-Cvjetković, et al. West Nile virus 'circulation' in Vojvodina, Serbia: Mosquito, bird, horse and human surveillance. Mol Cell Prob, 2017; 31:28-36.

${ }^{[51]}$ Stevanovic V, Vilibic-Cavlek T, Savic V, Hadina S, Staresina V, Barbic $\mathrm{Lj}$. Emergent and re-emergent flaviviruses in Croatia challenges of surveillance. Book of Abstracts. Emerging Viruses 2015 Conference. Nottingham, United Kingdom, 27-29 July, 2015, p18

${ }^{[52]}$ Stevanović V, Vilibić-Čavlek T, Barbić Lj. One health approach in human and animal infectious diseases control. Book of Abstracts. 7th International Congress "Veterinary Science and Profession", Zagreb, 5-7 October, 2017, p176 